\title{
Assessment of the nitrification process in a culture of pacific white shrimp, using artificial substrate and bacterial inoculum in a biofloc technology system (BFT)
}

\author{
Nathalia Brenda Veiga dos Santos ${ }^{1 *}$ (iD) Plínio Schmidt Furtado ${ }^{1}$ iD Dionéia Evangelista César ${ }^{2}$ iD \\ Wilson Wasielesky Junior ${ }^{1}$ iD
}

'Estação Marinha de Aquacultura, Instituto de Oceanografia, Universidade Federal do Rio Grande (FURG), 96210-030, Rio Grande, RS, Brasil. E-mail: nathaliabvds@gmail.com. *Corresponding author.

${ }^{2}$ Laboratório de Ecologia e Biologia Molecular, Instituto de Ciências Biológicas, Universidade Federal de Juiz de Fora (UFJF), Juiz de Fora, MG, Brasil.

ABSTRACT: Litopenaeus vannamei is the most cultured marine shrimp in all types of systems including the Bioflocs Technology System (BFT). Bioflocs are formed by microorganisms, among these, autotrophic bacteria are responsible for the nitrification process. This study aimed to identify and promote the development of nitrifying bacteria by adding artificial substrates and biofloc inoculum in L. vannamei culture in a BFT system. The experiment consisted of four treatments with three replics (4x3) as follows: (1) Control: clear water in which bioflocs were formed; (2) IN (10\%): clear water with biofloc inoculum (10\%); (3) IB: clear water with substrate (immature "bioballs"); and (4) MB: clear water with mature "bioballs" inoculum from a recirculation system. Treatments were stocked with shrimp juveniles (4.92 $\pm .45 \mathrm{~g})$ in 12 tanks with $200 \mathrm{~L}$ working volume at a stocking density of 200 shrimp $/ \mathrm{m}^{3}$. Shrimps were fed twice a day with a commercial feed (38\% CP) following a feeding table, and daily observations intake were made over the four weeks of the experiment. Biofloc and "bioballs" samples were collected to detect the growth of the population of nitrifying and heterotrophic bacteria by FISH. There was no significant difference between treatments $(P>0.05)$ for survival, obtaining mean values greater than $88 \%$. The IN $(10 \%)$ treatment had lower concentrations of ammonia and nitrite, and nitrate concentration increased, while MB had a higher weight and biomass final, productivity, weekly weight gain and lower conversion of apparent feed for production performance results.

Key words: heterotrophic bacteria, nitrifying bacteria, "bioballs", bioflocs, FISH (Fluorescent in situ Hybridization).

Avaliação do processo de nitrificação no cultivo do camarão branco do pacífico Litopenaeus vannamei com uso de substrato artificial e inóculo de bactérias em sistema de bioflocos (BFT)

RESUMO: Litopenaeus vannamei é o camarão marinho mais cultivado em todos os tipos de sistemas, incluindo o Sistema de Tecnologia de Bioflocos (BFT). Os bioflocos são formados por microorganismos, entre estes, bactérias autotróficas que são responsáveis pelo processo de nitrificação. Este estudo teve como objetivo identificar e promover o desenvolvimento de bactérias nitrificantes pela adição de substratos artificiais e inóculo de bioflocos no cultivo de L. vannamei em sistema BFT. O experimento consistiu de quatro tratamentos com três repetições (4x3), sendo: (1) Controle: água limpa, na qual foram formados os bioflocos; (2) IN (10\%): água limpa com inóculo de bioflocos (10\%); (3) BI: água limpa com substrato ("bioballs" imaturos); e (4) BM: água limpa com inóculo de "bioballs" maduros de um sistema de recirculação. Para tanto, os tratamentos foram estocados com juvenis de camarão (4,92 $\pm 0,45 \mathrm{~g})$ em 12 tanques com $200 \mathrm{~L}$ de volume útil com densidade de 200 camarões $/ m^{3}$. Os camarões foram alimentados duas vezes ao dia com ração comercial (38\% PB) seguindo uma tabela de alimentação, e observações diárias foram feitas ao longo das quatro semanas de experimento. Amostras de bioflocos e "bioballs" foram coletadas para detectar o crescimento da população de bactérias nitrificantes e heterotróficas por FISH. Não houve diferença significativa entre os tratamentos $(P>0,05)$ para sobrevivência, obtendo-se valores médios superiores a 88\%. O tratamento com IN (10\%) apresentou menores concentrações de amônia e nitrito, e a concentração de nitrato aumentou, enquanto o BM apresentou maior peso e biomassa final, produtividade, ganho de peso semanal e menor conversão alimentar aparente para resultados de desempenho zootécnico.

Palavras-chave: Bactérias heterotróficas, bactérias nitrificantes, "bioballs”, bioflocos, FISH (Hibridização in Situ Fluorescente).

\section{INTRODUCTION}

The bioflocs technology system (BFT) is based on the growth of microorganisms in the culture medium, benefiting from zero or minimal water exchange (SCHRYVER et al., 2008), and it is composed of microorganisms (bacteria, ciliates, diatoms, etc.), feces, feed remains, and carapace, among others. Microorganisms have two main functions: maintaining water quality by transforming the nitrogenous compounds into digestible protein (nitrifying and heterotrophic bacteria) and animal 
nutrition, increasing crop viability, reducing apparent feed conversion and feeding costs, which represent the $50 \%$ of total cost of aquaculture production due to the high cost of protein in commercial diets (SCHVEITZER et al., 2013). The nitrification is a crucial process for culture in biofloc systems. It is the transformation of ammonia into nitrate by autotrophic nitrifying bacteria, depending on the concentrations of ammonia and nitrite, the carbon/nitrogen ratio, temperature, $\mathrm{pH}$, dissolved oxygen, alkalinity, and organic and inorganic carbon (EBELING et al., 2006).

Specific species of autotrophic bacteria absorb the inorganic carbon present in the system known as Ammonia-Oxidants (AOB) and NitriteOxidants (NOB). The AOBs have higher efficiency in the transformation of nitrogen in relation to heterotrophic bacteria, but they take longer to oxidize the ammonia in nitrite and belong to the genera Nitrosomonas, Nitrosococcus, Nitrospira, Nitrosolobus and Nitrosovibrio. The NOB oxidation of nitrite to nitrate mostly belong to the genera Nitrobacter, Nitrococcus and Nitrospira, but they have a slower growth than the AOBs, accumulating a significant amount of nitrite in the system (SERRA et al., 2015).

It was observed that the reuse of a minimum inoculum of $2.5 \%$ of water from a previous crop to produce L. vannamei in a BFT system accelerated the formation of microbial aggregates in water (KRUMMENAUER et al., 2014) and that the use of artificial substrates increases the fixation of nitrifying bacteria, contributing to better maintenance of water quality in the system (SCHVEITZER et al., 2013; FURTADO et al., 2015b).

To verify the adherence of the bacteria to the substrate and their presence in the culture water, the FISH molecular technique, which relies on the binding of fluorescent labels to DNA probes and the binding of these probes to ribosomal RNA (rRNA) of the bacteria, was performed. However, to improve the nitrification process in $L$. vannamei culture in a BFT system, the objective of this study was to promote and identify the development of nitrifying bacteria through the addition of artificial substrates ("bioballs") and biofloc inoculum.

\section{MATERIALS AND METHODS}

\section{Location and facilities}

Marine Station of Aquaculture, Institute of Oceanography from Universidade Federal do Rio Grande (EMA/IO/FURG).

\section{Origins of shrimps}

Nauplii of L. vannamei were purchased from Aquatec Ltda. (Canguaretama/RN), and after their arrival at EMA, they were kept in the larval sector and cultivated. They were later stored in a nursery $\left(1500 / \mathrm{m}^{2}\right)$ in the BFT system, transferred to the fattening sector and grown until they reached an average weight of $4.92 \pm 0.45 \mathrm{~g}$. Only then were they allocated to the experimental units $(200 \mathrm{~L})$, with 40 shrimps/tank (200 shrimps $\left./ \mathrm{m}^{3}\right)$.

\section{Experimental design}

The experiment consisted of four treatments with three replicates each, as follows: (1) Control: clear water in which bioflocs were formed; (2) IN (10\%): clear water with biofloc inoculum $(10 \%)$; (3) IB: clear water with substrate (immature "bioballs") and (4) MB: clear water with mature "bioballs" inoculum from a recirculation system. Quality parameters of the culture water of shrimp origin and mature "bioballs" were analyzed before the start of the experiment (Table 1).

The shrimps were fed commercial feed (Guabi-potimar 38\% CP), with the aid of trays, twice a day (08:00 and 17:00) for four weeks. This value was then adjusted according to the estimated weekly biomass. A total of $1 \mathrm{ppm}$ of probiotic (PRO-W Sanolife) was added prophylactically to the culture water once per week, as recommended by the manufacturer (INVE). The commercial probiotic mixture (Sanolife-ProW ${ }^{\circledR}$ - INVE Aquaculture) used in this study is composed by Bacillus subtilis and Bacillus Licheniformes strains, in a bacterial concentration of $5 \cdot 10^{10} \mathrm{cfu} / \mathrm{g}$.

Table 1 - Quality of cultivation water of origin of shrimp and bioballs.

\begin{tabular}{lcc}
\hline Water quality & Bioflocs & "Bioballs" \\
\hline TA-N $\left(\mathrm{N}-\left(\mathrm{NH}_{3}+\mathrm{NH}_{4}{ }^{+}\right) \mathrm{mg} / \mathrm{L}\right)$ & 0.08 & 0.06 \\
$\mathrm{~N}^{-\mathrm{NO}_{2}}{ }^{-}(\mathrm{mg} / \mathrm{L})$ & 0.03 & 0.03 \\
$\mathrm{~N}^{-\mathrm{NO}_{3}}(\mathrm{mg} / \mathrm{L})$ & 52.0 & 11.0 \\
Alkalinity $\left(\mathrm{mg} / \mathrm{L} \mathrm{CaCO}_{3}\right)$ & 125.0 & 180.0 \\
$\mathrm{pH}$ & 7.20 & 7.95 \\
$\mathrm{Salinity}(\mathrm{g} / \mathrm{L})$ & 35.0 & 31.0 \\
Temperature $\left({ }^{\circ} \mathrm{C}\right)$ & 24.0 & 25.2 \\
TSS $(\mathrm{mg} / \mathrm{L})$ & 250 & 50 \\
\hline D.O. $(\mathrm{mg} / \mathrm{L})$ & 5.04 & 6.52 \\
\hline
\end{tabular}

TA-N Total Ammonia Nitrogen; ${\mathrm{N}-\mathrm{NO}_{2}-;}^{-} \mathrm{N}_{-\mathrm{NO}_{3}-;}$ pH; TSSTotal Suspended Solids; D.O.-Dissolved oxygen. 
The "bioballs" were allocated to plastic canvas pillows with a $5 \mathrm{~mm}$ opening $(34 \mathrm{cmL} x$ $18 \mathrm{cmW} \times 8 \mathrm{cmH}$ ), each containing 40 "bioballs" of $32 \mathrm{~mm}^{2}$. They were attached to the edges of the tanks with nylon threads and remained submerged throughout the experiment. The number of "bioballs" was based on the bottom area of the tank $\left(0.36 \mathrm{~m}^{2}\right)$.

\section{Organic fertilization}

Bioflocs were inoculated from a culture system where the shrimp were allocated until reaching an average weight of $4.92 \pm 0.45 \mathrm{~g}$. Sugarcane molasses containing $37.46 \%$ carbon was used as the source of organic carbon.

For the addition of the carbon source, the research of EBELING et al. (2006) was used, where $6 \mathrm{~g}$ of carbon is required to convert $1 \mathrm{~g}$ of ammonia to bacterial biomass, favoring a nominal $\mathrm{C} / \mathrm{N}$ ratio of approximately $15: 1$. When total ammonia exceeded $1 \mathrm{mg} / \mathrm{L}$, organic fertilization was performed to adjust the $\mathrm{C} / \mathrm{N}$ ratio in all tanks.

\section{Physical and chemical parameters of water}

The water temperature was controlled $(\sim 28$

${ }^{\circ} \mathrm{C}$ ) with the use of heaters with thermostats distributed in the tanks. The aeration was provided by a blower and distributed by two hoses with porous stones/tank. Salinity was maintained at approximately $32 \mathrm{~g} / \mathrm{L}$ and was measured once a week with the aid of a portable refractometer. When necessary, dechlorinated fresh water was added to correct it.

The parameters of waterquality, temperature, $\mathrm{pH}$ and D.O. were measured twice a day using the multiparameter. The experiment was carried out in a room with a controlled temperature of $30{ }^{\circ} \mathrm{C}$. The concentrations of total ammonia nitrogen $\left(\mathrm{NH}_{3}+\mathrm{NH}_{4}^{+}\right)$ and nitrite $\left(\mathrm{N}^{-\mathrm{NO}_{2}}{ }^{-}\right)$were measured daily (UNESCO, 1983; BENDSCHNEIDER \& ROBINSON, 1952), and nitrate $\left(\mathrm{N}-\mathrm{NO}_{3}^{-}\right)$was measured every seven days (AMINOT \& CHAUSSEPIED, 1983).

Alkalinity was measured twice a week (APHA, 1999); when it reached concentrations below $125 \mathrm{mg} / \mathrm{LCaCO}_{3}$, which was determined every three days, $0.03 \mathrm{~g} / \mathrm{L}$ of hydrated lime $\left(\mathrm{Ca}(\mathrm{OH})_{2}\right)$ was added to the tanks to maintain the value above the recommended minimum (FURTADO et al., 2014).

The TSS were measured weekly (STRICKLAND \& PARSONS, 1972), with the value estimated by the difference between final and initial weight of each filter. The water of the tanks was filtered with a mesh of 50 microns when the solids reached concentrations higher than $500 \mathrm{mg} / \mathrm{L}$ (GAONA et al., 2015).

\section{Methodology FISH}

Water samples from all tanks were collected weekly for the identification of nitrifying (Nitrospira, Nitrobacter spp., Nitrosomonadales, Nitrospira moscoviensis, N. marina, Nitrosomonas marina like, Nitrococcus) and heterotrophic bacteria (Pseudomonas spp.) The FISH methodology was used, with $4.5 \mathrm{ml}$ of water/tank in Falcon tube (15 $\mathrm{ml}$ ) and $0.5 \mathrm{ml}$ of $2 \%$ paraformaldehyde solution, also used to fix the substrates (four external area pins of the bioballs) of the IB and MB treatments collected in triplicate in $1.5 \mathrm{ml}$ Eppendorfs.

The technique was performed according to theprotocoloftheLaboratory ofEcologyandMolecular Biology of Microorganisms - LEBIOMM - adapted from COTTRELL \& KIRCHMAN (2003), where the samples were generally fixed, sonicated, centrifuged, filtered, hybridized, washed, and stained with DAPI; slides were assembled and visualized using an epifluorescence microscope. Probes used are specified in table 2 .

\section{Zootechnical performance of shrimps}

The initial mean weight of the shrimp/ tank was estimated from the initial biometry of 12 individuals. During the experiment, weekly biometrics were performed with 12 shrimp/tank. Samples were randomized and the shrimps individually weighed, using a digital scale with accuracy of $0.01 \mathrm{~g}$, adjusting the feed throughout the experiment according to the estimate of the calculated biomass. In the final biometry, the shrimp from each tank were counted and weighed individually.

The experimental performance was evaluated by the final biomass (g), weekly weight gain (g/week), final weight (g), survival (\%), productivity $\left(\mathrm{kg} / \mathrm{m}^{3}\right)$ and feed conversion ratio (FCR).

\section{Statistical analysis}

The comparison between means of different treatments was performed by analysis of one-way variance (ANOVA). The data were assessed for homoscedasticity and normality, and the means were submitted to the Tukey test $(\mathrm{P}<0.05)$. Some data were transformed mathematically before being analyzed, and percentage values (e.g., survival) were transformed into a square root arc. Nitrogen compound data were analyzed using two-way ANOVA among treatments for each week of cultivation.

\section{RESULTS}

The values of temperature, dissolved oxygen, $\mathrm{pH}$, alkalinity and salinity did not differ

Ciência Rural, v.49, n.6, 2019. 
Table 2 - Probes used to identify and count the bacteria present in the samples.

\begin{tabular}{|c|c|c|c|c|c|c|}
\hline Probe & $\begin{array}{l}\text { Sequence of probe } \\
\qquad\left(5^{\prime}-3^{\prime}\right)\end{array}$ & $\begin{array}{l}\text { Place of destination } \\
\text { (rRNA) and position }\end{array}$ & Specificity & ${ }^{*} \% \mathrm{FA}$ & ${ }^{* *} \mathrm{NaCl}(\mathrm{mM})$ & Reference \\
\hline $\mathrm{NON}$ & $\begin{array}{c}\text { TAGTGACGCCG } \\
\text { TCGA }\end{array}$ & - & Negative control & 30 & 0,9 & $\begin{array}{l}\text { YOKOKAWA \& } \\
\text { NAGATA (2005) }\end{array}$ \\
\hline NIT3 & $\begin{array}{c}\text { CCTGTGCTCCAT } \\
\text { GCTCCG }\end{array}$ & $16 \mathrm{~S}(1030-1047)$ & Nitrobacter spp.- $\mathrm{NOB}$ & 40 & 56 & $\begin{array}{c}\text { WAGNER et al. } \\
\text { (1996) }\end{array}$ \\
\hline NITCOC206 & $\begin{array}{c}\text { CGGTGCGAGCT } \\
\text { TGCAAGC }\end{array}$ & - & $\begin{array}{c}\text { Nitrococcus mobilis- } \\
\mathrm{AOB}\end{array}$ & 20 & - & $\begin{array}{l}\text { JURETSCHKO } \\
\text { et al. (1998) }\end{array}$ \\
\hline NSO190 & $\begin{array}{c}\text { CGATCCCCTGCT } \\
\text { TTTCTCC }\end{array}$ & $16 \mathrm{~S}(190-208)$ & $\begin{array}{c}\text { Nitrosomonadales- } \\
\text { AOB }\end{array}$ & 35 & 20 & $\begin{array}{c}\text { MOBARRY et al. } \\
(1996)\end{array}$ \\
\hline NSO1225 & $\begin{array}{c}\text { CGCCATTGTATT } \\
\text { ACGTGTGA }\end{array}$ & $16 \mathrm{~S}(1224-1243)$ & $\begin{array}{c}\text { Nitrosomonadales- } \\
\text { AOB }\end{array}$ & 35 & 80 & $\begin{array}{c}\text { MOBARRY et al. } \\
(1996)\end{array}$ \\
\hline NSMR76 & $\begin{array}{l}\text { CCC CCC TCT } \\
\text { TCT GGA TAC }\end{array}$ & $16 \mathrm{~S}(132-149)$ & $\begin{array}{c}\text { Nitrosomonas marina- } \\
\text { like-AOB }\end{array}$ & 20 & 225 & $\begin{array}{l}\text { BURRELL et al. } \\
\text { (2001) }\end{array}$ \\
\hline NTSPA685 & $\begin{array}{c}\text { CAC CGG GAA } \\
\text { TTC CGC GCT } \\
\text { CCT C }\end{array}$ & $16 \mathrm{~S}(664-685)$ & $\begin{array}{c}\text { Nitrospira moscoviensis, } \\
\text { Nitrospira marina- } \\
\text { NOB }\end{array}$ & 20 & 225 & $\begin{array}{l}\text { BURRELL et al. } \\
\text { (2001) }\end{array}$ \\
\hline NTSPA712 & $\begin{array}{c}\text { CGCCTTCGCCAC } \\
\text { CCGGCCTTCC }\end{array}$ & - & $\begin{array}{c}\text { Phylum Nitrospira- } \\
\text { NOB }\end{array}$ & 50 & 28 & $\begin{array}{l}\text { DAIMS et al. } \\
\qquad(2001)\end{array}$ \\
\hline PAE997 & $\begin{array}{c}\text { TCTGGAAAGTTC } \\
\text { TCAGCA }\end{array}$ & $16 \mathrm{~S}(997-1014)$ & $\begin{array}{l}\text { Pseudomonas spp.- } \\
\text { Heterotrophic }\end{array}$ & 35 & - & $\begin{array}{l}\text { AMANN et al. } \\
\text { (1996) }\end{array}$ \\
\hline
\end{tabular}

*Percentage of formamide (FA) in the hybridization solution. ${ }^{* *}$ Concentration of sodium chloride in the wash solution.

Analysis performed at the Universidade Federal de Juiz de Fora (UFJF), at LEBIOMM, located in the Department of Biology in Minas Gerais.

significantly $(\mathrm{P}>0.05)$. Meanwhile the values of ammonia and nitrite were lower $(\mathrm{P}<0.05)$ in the IN $(10 \%)$ while nitrate was higher in relation to the other treatments. An increase in TSS was observed in all treatments throughout the experiment, where IN $(10 \%)$ was significantly different $(\mathrm{P}<0.05)$ from the others (Table 3 ).
More organic carbon was added to the culture water of the control and IB treatments $(\mathrm{P}<0.05)$, with $8.68 \%$ less carbon added to the IN $(10 \%)$ treatment, $117.9 \%$ more carbon to IB and $50.5 \%$ less to $\mathrm{MB}$ in relation to the amount added to the control treatment (Figure 1). A significant difference was reported only in the total number of

Table 3 - Mean \pm standard deviation $(n=3)$ of the water quality parameters of the different treatments - (1) Control: clear water in which bioflocs were formed; (2) IN (10\%): clear water with biofloc inoculum (10\%); (3) IB: clear water with substrate (immature "bioballs") and (4) MB: clear water with mature "bioballs" inoculum from a recirculation system- over the 29 days of experiment with L. vannamei.

\begin{tabular}{|c|c|c|c|c|}
\hline Parameters & Control & IN $(10 \%)$ & IB & MB \\
\hline Temperature $\left({ }^{\circ} \mathrm{C}\right)$ & $28.79 \pm 0.56$ & $28.95 \pm 0.51$ & $29.24 \pm 0.48$ & $28.39 \pm 0.65$ \\
\hline Dissolved Oxygen (mg/L) & $5.76 \pm 0.15$ & $5.77 \pm 0.17$ & $5.66 \pm 0.14$ & $5.79 \pm 0.15$ \\
\hline $\mathrm{pH}$ & $8.02 \pm 0.16$ & $7.97 \pm 0.12$ & $8.09 \pm 0.12$ & $8.01 \pm 0.16$ \\
\hline Alkalinity $\left(\mathrm{mg} / \mathrm{L} \mathrm{CaCO}_{3}\right)$ & $124.07 \pm 27.01$ & $117.41 \pm 23.61$ & $137.41 \pm 17.50$ & $131.30 \pm 24.08$ \\
\hline Salinity (g/L) & $32.31 \pm 0.53$ & $33.21 \pm 0.56$ & $32.51 \pm 0.57$ & $32.37 \pm 0.47$ \\
\hline Total Suspended Solids (mg/L) & $236.67 \pm 225.37^{b}$ & $424.0 \pm 278.80^{\mathrm{a}}$ & $213.0 \pm 198.16^{\mathrm{b}}$ & $199.0 \pm 215.92^{\mathrm{b}}$ \\
\hline Ammonia (mg/L) & $0.44 \pm 0.42^{\mathrm{b}}$ & $0.04 \pm 0.04^{\mathrm{a}}$ & $0.61 \pm 0.53^{\mathrm{b}}$ & $0.37 \pm 0.35^{\mathrm{b}}$ \\
\hline Nitrite $(\mathrm{mg} / \mathrm{L})$ & $4.34 \pm 2.82^{\mathrm{c}}$ & $0.14 \pm 0.06^{\mathrm{a}}$ & $5.65 \pm 3.18^{\mathrm{d}}$ & $1.82 \pm 1.21^{\mathrm{b}}$ \\
\hline Nitrate (mg/L) & $11.92 \pm 1.99^{\mathrm{b}}$ & $25.06 \pm 3.95^{\mathrm{a}}$ & $6.92 \pm 2.81^{\mathrm{b}}$ & $10.83 \pm 2.97^{\mathrm{b}}$ \\
\hline
\end{tabular}

Different letters overlapping on the same line indicate significantly different means $(\mathrm{P}<0.05)$. 


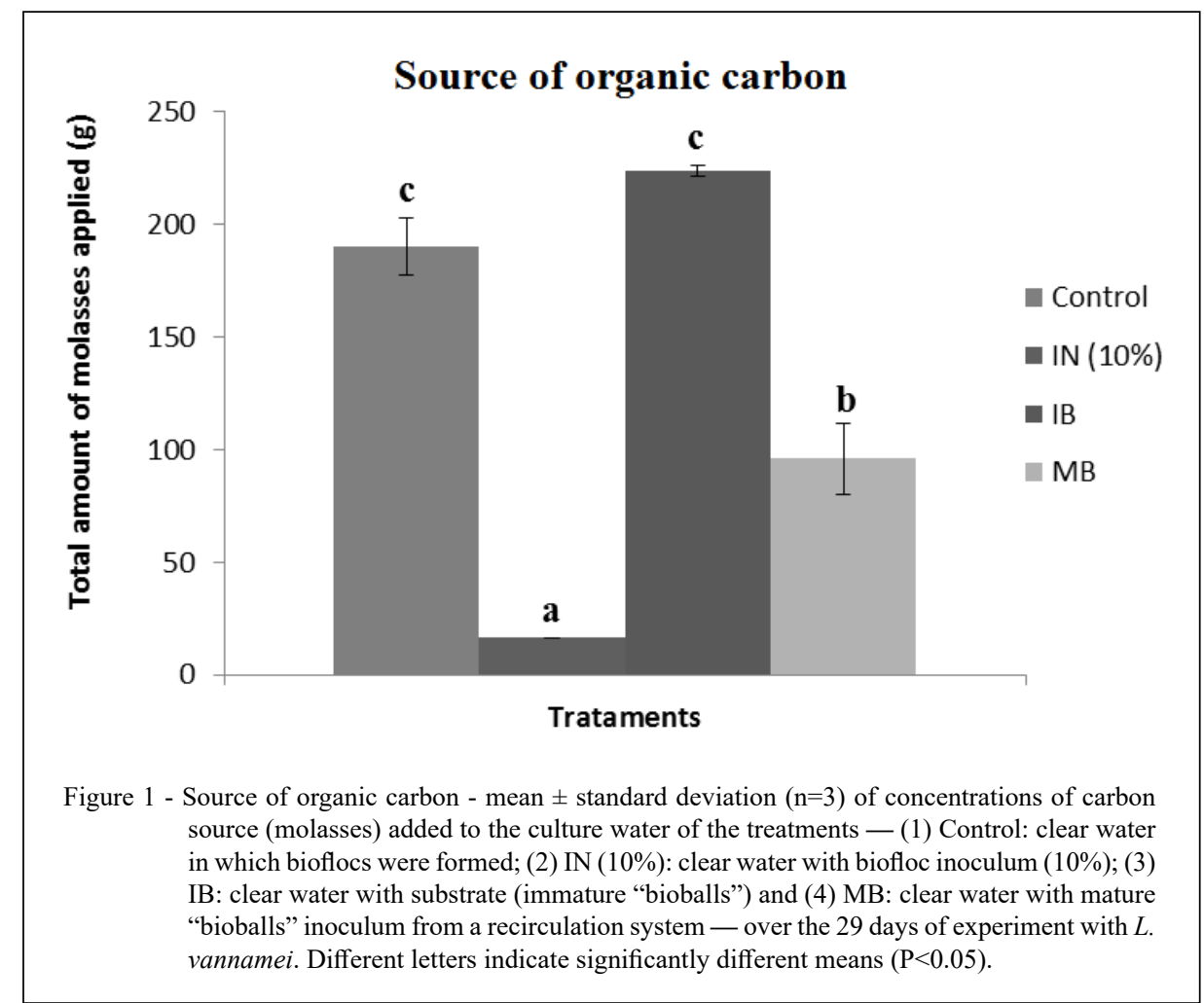

microorganisms $(\mathrm{P}<0.05)$ collected on 16th day of experiment (Figure 2).

There was a significant difference $(\mathrm{P}<0.05)$ in the number of Nitrococcus mobilis and Nitrossomonadales bacteria in the bioballs samples on 23th and 29th day in which IB had more bacteria that MB. For all other probes, throughout the experiment, bacterial densities $(105 \mathrm{cells} / \mathrm{g})$ were statistically the same $(\mathrm{P}>0.05)$ among treatments (Figure 3$)$. There was no significant difference $(\mathrm{P}>0.05)$ in survival, weight and initial biomass, final weight and weekly weight gain among treatments (Table 4).

The final biomass and productivity were higher in the MB treatment $(\mathrm{P}<0.05)$ than IN $(10 \%)$, and there was no significant difference $(\mathrm{P}>0.05)$ in relation to control and IB treatments. The FCR in IN $(10 \%)$ was statistically similar $(\mathrm{P}>0.05)$ to the control and different from the others $(\mathrm{P}<0.05)$. The FCR in the control was equal $(\mathrm{P}>0.05)$ to all other treatments.

\section{DISCUSSION}

The water quality parameters for L. vannamei production were kept within the standards recommended by VAN WYK, P. \& SCARPA, J. (1999). Expected increases in solids concentrations in all treatments were observed due to the induction of the formation of the bioflocs, with control, IB and $\mathrm{MB}$ treatments below the limits recommended of $500-600 \mathrm{mg} / \mathrm{L}$ and within the concentrations of TSS $(100-300 \mathrm{mg} / \mathrm{L})$ recommended during the formation of bioflocs (GAONA et al., 2015). Except for the IN $(10 \%)$ treatment that started with a higher solids content due to the $10 \%$ BFT inoculum, lower ammonia and nitrite values and higher nitrate values were reported because it was already colonized with autotrophic and heterotrophic bacteria.

The values of TA-N and N-NO2- observed throughout the experiment were lower than the recommended maximum values for the species (3.95 $\mathrm{mg} / \mathrm{L}$ and $25.7 \mathrm{mg} / \mathrm{L}$, respectively) (LIN \& CHEN, 2001, 2003). Nitrate values, which remained below the lethal range of $300 \mathrm{mg} / \mathrm{L}$ throughout the crop (FURTADO et al., 2015a), did not affect the zootechnical performance of shrimps.

A lower concentration of carbon in the IN $(10 \%)$ treatment was added in relation to the other treatments, since it presented lower peaks of ammonia throughout the experiment due to the higher colonization of bacteria NOB. It has been reported that inoculating nitrifying bacteria maybe a viable alternative for promoting their development in the system.

This finding means that during the experiment, the bacteria were colonizing the 


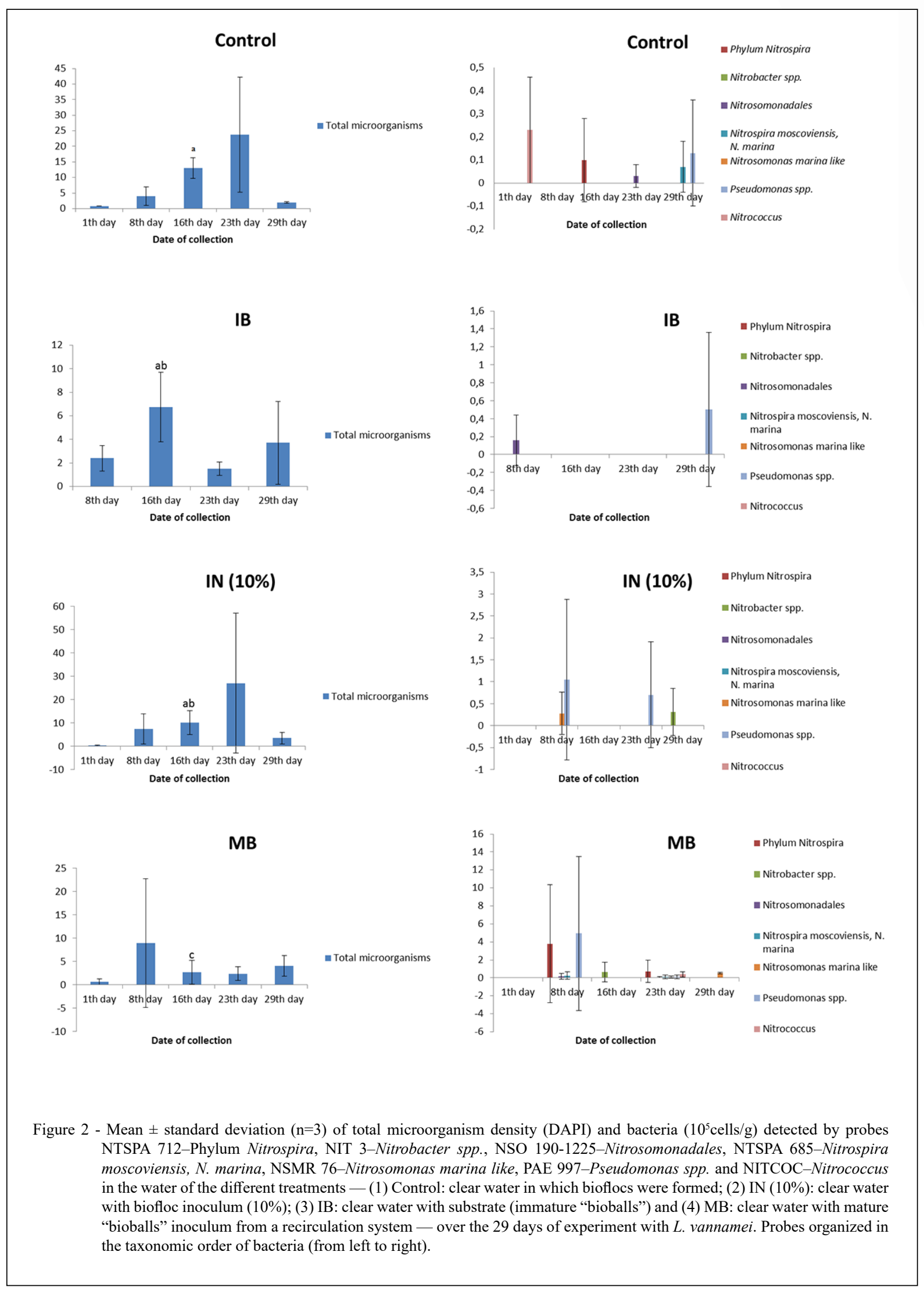

Ciência Rural, v.49, n.6, 2019. 

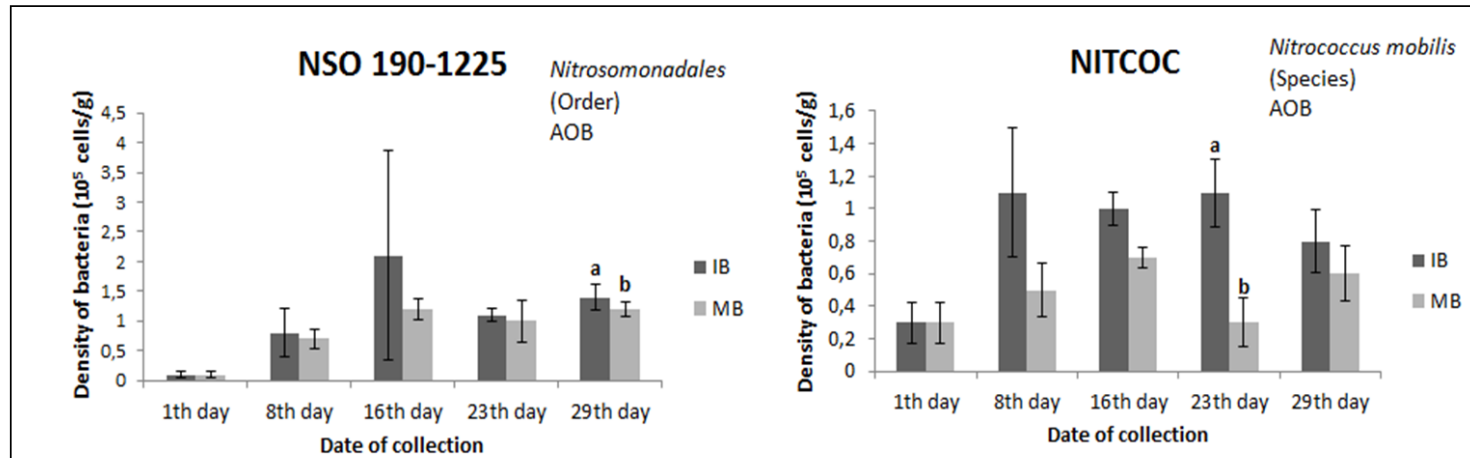

Figure 3 - Total bacteria density ( $10^{5}$ cells/g) detected by probes NSO190-1225 - Nitrosomonadales (a) and NITCOC - Nitrococcus mobilis (b) on the outside of the treatments "bioballs" — (3) IB: clear water with substrate (immature "bioballs") and (4) MB: clear water with mature - over the 29 days of experiment with $L$. vannamei. Results are presented as mean \pm standard error $(n=3)$. Different letters indicate significantly different means $(P<0.05)$. Gaps are organized according to the taxonomic order of the bacteria.

medium and oxidizing the ammonia in nitrite in all the treatments. Nitrite is the smaller value of these compounds reported in the treatments IN $(10 \%)$ and $\mathrm{MB}$, in which bacteria were inoculated at the beginning of the experiment, proving that they remained alive and active and that they presented nitrate concentrations more rapidly, as was also observed by KRUMMENAUER et al., (2014).

In the present study, a greater number of bacteria adhering to the "bioballs" was found than in the culture water (Control treatment), as was also observed by UMESH et al. (1999). The same cannot be said for the treatment with IN $(10 \%)$, because a great amount of bacteria was added in the water of the same.

The IN $(10 \%)$ and MB treatments received a bacterial inoculum at the beginning of the experiment, where IN (10\%) showed a higher concentration of TSS, leading to a higher contribution of nitrate in this system in relation to the others and MB to a higher volume of biofilms, which were already adhered to mature bioballs.

In the present study, different types of bacteria were present in the system, such as Pseudomonas spp., which are heterotrophic bacteria responsible for the reduction of nitrate and phosphate, and nitrate removed by denitrifying microorganisms.

The species AOB, Nitrococcus mobilis, is reported only in marine environments and is an obligate halophile. It oxidizes nitrite to nitrate (HNO2 $+\mathrm{H} 2 \mathrm{O}$ to $\mathrm{HNO} 3$ ) and has been reported at lower concentrations than other nitrification bacteria (e.g. Nitrosomonas sp.), as can be observed in the present study, in which it was reported only in the control and MB treatments in low quantities.
Most species of Nitrospira moscoviensis and N. Marina are obliged chemoautotrophic, important in marine habitats, and generally found in fresh and/or salt water. Under aerobic conditions, they consume inorganic carbon ( $\mathrm{HCO} 3-$ and $\mathrm{CO} 2$ ) and pyruvate, their doubling time is every $12-32$ hours (EHRICH et al., 1995). In this study, it was found in the control and MB treatments.

The AOB Nitrosomonas marine Proteobacterium is an obligatory, aerobic, gramnegative halophile of the genus Nitrosomonas (BURRELL et al., 2001). It was observed only in the IN $(10 \%)$ and $\mathrm{MB}$ treatments because they were stabilized systems with a longer time of colonization.

Specimens of the genus Nitrobacter are facultative chemoautotrophic, they are reported in terrestrial and aquatic environments (EHRICH et al., $1995)$ and were present only in the IN (10\%) and MB treatments due to the higher concentration of NOB in these systems, responsible for the transformation of nitrite into nitrate, having IN (10\%) the highest concentration of nitrate between the treatments.

In the literature on nitrifying systems, mention is made of a percentage of nitrifying agents in approximately $10 \%$ of the total bacterial population (HARMS et al., 2003), as can be observed in the present study for the concentration of AOB and NOB on the extraneous part of "bioballs" of the IB and MB treatments. In addition, a greater amount of nitrifying bacteria than heterotrophic bacteria was observed in the substrates.

High NOB concentrations in relation to AOB have been reported in several studies. HARMS et al. (2003) found 5 times more cells of Nitrospira $s p$. than $\mathrm{AOB}$ in full-scale systems treating 
Table 4 - Means \pm standard deviation of the main parameters of zootechnical performance in the different treatments- (1) Control: clear water in which bioflocs were formed; (2) IN (10\%): clear water with biofloc inoculum (10\%); (3) IB: clear water with substrate (immature "bioballs") and (4) MB: clear water with mature "bioballs" inoculum from a recirculation system- over the 29 days of experiment with L. vannamei.

\begin{tabular}{|c|c|c|c|c|}
\hline Zootechnical performance & Control & IN $(10 \%)$ & IB & MB \\
\hline Survival (\%) & $90.0 \pm 9.0$ & $88.8 \pm 1.8$ & $99.2 \pm 1.4$ & $98.0 \pm 2.5$ \\
\hline Initial Weight (g) & $4.92 \pm 0.19$ & $4.92 \pm 0.42$ & $4.92 \pm 0.16$ & $4.92 \pm 0.23$ \\
\hline Final Weight (g) & $10.5 \pm 0.6$ & $9.7 \pm 0.8$ & $10.2 \pm 0.9$ & $10.7 \pm 0.7$ \\
\hline Initial Biomass (g) & $196 \pm 7.34$ & $196 \pm 7.28$ & $196 \pm 19.71$ & $196 \pm 5.71$ \\
\hline Final Biomass (g) & $375.6 \pm 24.9^{\mathrm{ab}}$ & $357.9 \pm 3.6^{\mathrm{b}}$ & $406.4 \pm 32.9^{\mathrm{ab}}$ & $418.9 \pm 25.6^{\mathrm{a}}$ \\
\hline Productivity $\left(\mathrm{kg} / \mathrm{m}^{3}\right)$ & $0.90 \pm 0.12^{\mathrm{ab}}$ & $0.81 \pm 0.02^{\mathrm{b}}$ & $1.05 \pm 0.16^{\mathrm{ab}}$ & $1.11 \pm 0.15^{\mathrm{a}}$ \\
\hline Weekly Weight Gain (g) & $1.39 \pm 0.16$ & $1.20 \pm 0.21$ & $1.33 \pm 0.21$ & $1.46 \pm 0.18$ \\
\hline FCR & $1.8 \pm 0.20^{\mathrm{ab}}$ & $2.0 \pm 0.04^{\mathrm{b}}$ & $1.4 \pm 0.19^{\mathrm{a}}$ & $1.4 \pm 0.22^{\mathrm{a}}$ \\
\hline
\end{tabular}

Different letters overlapping on the same line indicate significantly different means $(\mathrm{P}<0.05)$. FCR: Feed conversion rate.

municipal sewage. High concentrations of NOB were also observed in this study for the IN $(10 \%)$ and MB treatments in the biofloc samples, because the more mature the flake (the longer the formation time) the higher the concentration of NOB due to the amount of nitrite being formed the same.

In general, members of the Nitrospira spp. and/or Nitrosomonas oligotropha is the dominant AOB in environments with low N-NH4+ concentrations, whereas Nitrosomonas europaea and Nitrosococcus mobilis predominate in environments rich in ammonium ions, as seen in another research (LIMPIYAKORN et al., 2005). This phenomenon must have led to a higher concentration of AOB in the IB and Control treatments, due to the high ammonia rate in the system in relation to the others.

In general, in the biofloc samples, a higher concentration of nitrifying bacteria was observed in the MB treatment, with more NOB observed in IN $10 \%$ ), showing that these systems are more stabilized than the others. The IB showed a higher concentration of AOB, followed by the control, proving the occurrence of colonization of the systems.

For the substrate samples, a higher concentration of AOB was observed for the IB treatment, showing a colonization of the younger system. Meanwhile, MB obtained higher amounts of NOB and heterotrophic bacteria, proving to be an older and more stabilized system, with more bacteria adhering.

Studies conducted by SCHVEITZER et al. (2013) testing the density and the presence or absence of substrate for the cultivation of juvenile $\mathrm{L}$. vanname $i$ with a mean weight of $2.7 \pm 0.1 \mathrm{~g}$ in bioflocs for 34 days. The survival values $(70.6 \pm 17.1 \%)$, FCR
$(4.1 \pm 1.8)$ and weekly weight gains $(0.73 \pm 0.04 \mathrm{~g})$ obtained by them in the D238 treatment (238 shrimps/ $\mathrm{m}^{3}$ ) were lower than those found in the control in the present study Conversely, the D238+S treatment (238 shrimps $/ \mathrm{m}^{3}+$ substrate-polyethylene screens with 1.0 $\mathrm{mm}$ mesh) compared to the IB treatment obtained survival values $(95.2 \pm 2.9 \%)$, weekly weight gain $(1.40 \pm 0.05 \mathrm{~g})$ and FCR $(1.6 \pm 0.0)$ similar to those reported in the present study: $99.2 \pm 1.4 \%, 1.33 \pm 0.21$ $\mathrm{g}$ and $1.4 \pm 0,19$, respectively.

\section{CONCLUSION}

Inoculums of biofloc and "bioballs" are effective options for better nitrification in the system, and "bioballs" are an efficient substrate for a greater fixation of bacteria that increase the assimilation of the nitrogen compounds and; consequently, allow a greater production of microbial biofilm, helping to stabilize of these compounds in the system.

\section{ACKNOWLEDGEMENTS}

This work was supported by the Conselho Nacional de Desenvolvimento Científico e Tecnológico (CNPq), Coordenação de Aperfeiçoamento de Pessoal de Nível Superior (CAPES) and Ministério da Agricultura, Pecuária e Abastecimento (MAPA). Wasielesky, W.J. is research fellows of CNPq process 310652/2017-0.

\section{DECLARATION OF CONFLICT OF INTERESTS}

The authors declare no conflict of interest. The founding sponsors had no role in the design of the study; in the collection, analyses, or interpretation of data; in the writing of the manuscript, and in the decision to publish the results. 


\section{AUTHORS' CONTRIBUTIONS}

The authors thank the Universidade Federal do Rio Grande - FURG for the space and materials provided and teacher Dionéia, from the Laboratory of Ecology and Molecular Biology of UFJF, for assigning the laboratory for FISH analyzes and facilities for carrying out this research.

\section{REFERENCES}

AMANN, RUDOLF et al. In situ visualization of high genetic diversity in a naturalmicrobial community.Journalof Bacteriology LehrstuhlFu"rMikrobiologie, Technische Universita"tMu"nchen, Munich, Germany, v.178, n.12, p.3496-3500, Jun. 1996. Available from: $<$ http://jb.asm.org/content/178/12/3496.abstract $>$. Accessed: Jul. 27, 2018. doi: 10.1128/jb.178.12.3496-3500.1996.

AMINOT, A.; CHAUSSEPIED, M. Manual de análises em oceanografia química. In: BAUMGARTEN, M.G.Z et al. Análise Instrumental. Rio Grande: Baumgarten MGZ, Wallner-Kersanach M, Niencheski LFH, 1983. 2010 ed.

APHA. Standard methods for the examination of water and wastewater. New York: American Public Health Association (APHA), American Water Works Association (AWWA), Water Environment Federation (WEF), 1999.

BENDSCHNEIDER, K.; ROBINSON, R. J. A new spectrophotometric method for the determination of nitrite in sea water. Journal of Marine Research, University Of Washington, v.11, p.87-96, Jan. 1952. Available from: <https://digital.lib. washington.edu/researchworks/bitstream/handle/1773/15938/521. pdf? sequence=1>. Accessed: Aug. 14, 2015.

BURRELL, P.C. et al. Identification of bacteria responsible for ammonia oxidation in freshwater aquaria. Applied and Environmental Microbiology, Moorpark, v.67, n.12, p.5791-5800, Dec. 2001. Available from: <http://aem.asm.org/content/67/12/5791.short> Accessed: Jul. 28, 2018. doi: 10.1128/AEM.67.12.5791-5800.2001.

COTTRELL, M.T; KIRCHMAN, D.L. Contribution of major bacterial groups to bacterial biomass production (thymidine and leucine incorporation) in the Delaware estuary .Limnology and Oceanography, Lewes, v.48, n.1, p.168-178, Jan. 2003. Available from: <https://aslopubs.onlinelibrary.wiley.com/doi/abs/10.4319/ lo.2003.48.1.0168> Accessed: Jul. 28, 2018. doi: 10.4319/ lo.2003.48.1.0168

DAIMS, H. et al. In situ characterization of Nitrospira-Like Nitrite-Oxidizing Bacteria active in wastewater treatment plants. Applied and Environmental Microbiology, Freising, v.67, n.11, p.5273-5284, Nov. 2001. Available from: <http://aem.asm.org/ content/67/11/5273.short> Accessed: Apr. 06, 2016. doi: 10.1128/ AEM.67.11.5273-5284.2001.

EBELING, J.M. et al. Engineering analysis of the stoichiometry of photoautotrophic, autotrophic, and heterotrophic removal of ammonia-nitrogen in aquaculture systems. Aquaculture, [S.1.], v.257, n. 1-4, p. 346-358, Jun. 2006. Available from: $<$ https://www. sciencedirect.com/science/article/pii/S004484860600216X>. Accessed: Aug. 14, 2015. doi: 10.1016/j.aquaculture.2006.03.019.

EHRICH, S. et al. A new obligately chemolitho autotrophic, nitrite-oxidizing bacterium, Nitrospira moscoviensis sp.nov. and its phylogenetic relationship. Archives Microbiology, [S.1.], v.164, n.1, p.16-23, Jul. 1995. Available from: <https://www.ncbi. nlm.nih.gov/pubmed/7646315>. Accessed: Jul. 28, 2018. PMID: 7646315 .

FURTADO, P.S. et al. Application of different doses of calcium hydroxide in the farming shrimp Litopenaeus vannamei with the biofloc technology (BFT). Aquaculture International, Rio Grande, v.22, n.3, p.1009-1023, Jun. 2014. Available from: $<$ https://link.springer.com/article/10.1007/s10499-013-97239>. Accessed: Jul. 27, 2015. doi: 10.1007/s10499-013-9723-9.

FURTADO, P.S. et al. Effects of nitrate toxicity in the Pacific white shrimp, Litopenaeus vannamei, reared with biofloc technology (BFT). Aquaculture International, Rio Grande, v.23, n.1, p.315327, Feb. 2015a. Available from: <https://link.springer.com/ article/10.1007/s10499-014-9817-z>. Accessed: Mar. 16, 2016. doi: 10.1007/s10499-014-9817-z.

FURTADO, P.S. et al. The effect of different alkalinity levels on Litopenaeus vannamei reared with biofloc technology (BFT). Aquaculture International, Rio Grande, v.23, n.1, p.345358, Feb. 2015b. Available from: <https://link.springer.com/ article/10.1007/s10499-014-9819-x>. Accessed: Feb. 17, 2016. doi: 10.1007/s10499-014-9819-x.

GAONA, C.A.P. et al. Effect of different total suspended solids levels on a Litopenaeus vannamei (Boone, 1931) BFT culture system during biofloc formation. Aquaculture Research, Rio Grande, v.48, n.3, p.1-10, Dec. 2015. Available from: $<$ https://onlinelibrary.wiley. com/doi/abs/10.1111/are.12949>. Accessed: Mar. 21, 2016. doi: 10.1111/are.12949.

HARMS, G. et al. Real-time PCR quantification of nitrifying bacteria in a municipal waste water treatment plant. Environmental Science \& Technology, Knoxville, v.37, n.2, p.343-351, Jan. 2003. Available from: <https://pubs.acs.org/doi/full/10.1021/ es0257164>. Accessed: Jul. 28, 2018. doi: 10.1021/es0257164.

JURETSCHKO, S. et al. Combined molecular and conventional analyses of nitrifying bacterium diversity in activated sludge: Nitrosococcus mobilis and Nitrospira-Like bacteria as dominant populations. Applied and Environmental Microbiology, Hamburg, v.64, n.8, p.3042-3051, Aug. 1998. Available from: $<\mathrm{http}$ ://aem.asm.org/content/64/8/3042.full.pdf $+\mathrm{html}>$. Accessed: Apr. 29, 2016.

KRUMMENAUER, D, et al. The reuse of water on the culture of Pacific White Shrimp, Litopenaeus vannamei, in BFT system. Journal of the World Aquaculture Society, Rio Grande, v.45, n.1, p.3-14, Feb. 2014. Available from: <https://onlinelibrary. wiley.com/doi/abs/10.1111/jwas.12093 >. Accessed: Mar. 21, 2016. doi: 10.1111/jwas.12093.

LIMPIYAKORN, T. et al. Communities of ammonia-oxidizing bacteria in activated sludge of various sewage treatment plants in Tokyo. FEMS Microbiology Letters, Tokyo, v.54, n.2, p.205-217, Oct. 2005. Available from: <https://www.ncbi.nlm.nih.gov/pubmed/16332320> Accessed: Jul. 30, 2018. doi: 10.1016/j.femsec.2005.03.017.

LIN, Y.C; CHEN, J.C. Acute toxicity of ammonia on Litopenaeus vannamei Boone juveniles at different salinity levels. Journal of Experimental Marine Biology and Ecology, Keelung, v.259, n.1, p.109-119, Apr. 2001. Available from: <https://www.sciencedirect. com/science/article/pii/S0022098101002271>. Accessed: Mar. 01, 2016. doi: 10.1016/S0022-0981(01)00227-1. 
LIN, Y.C; CHEN, J.C. Acute toxicity of nitrite on Litopenaeus vannamei (Boone) juveniles at different salinity levels. Aquaculture, Keelung, v.224, n.1-4, p.193-201, Jun. 2003. Available from: <https://www.sciencedirect.com/science/article/ abs/pii/S0044848603002205>. Accessed: Mar. 01, 2016. doi: 10.1016/S0044-8486(03)00220-5.

MOBARRY, B.K et al. Phylogenetic probes for analyzing abundance and spatial organization of nitrifying bacteria. Applied and Environmental Microbiology, Evanston, v.62, n.6, p.2156-2162, Jun. 1996. Available from: <https://www.ncbi.nlm.nih.gov/pmc/articles/ PMC167993/>. Accessed: Apr. 06, 2016. PMCID: PMC167993.

SCHRYVER, P.D. et al. The basics of bio-flocs technology: The added value for aquaculture. Aquaculture, Ghent, v.277, n.3-4 p.125-137, Jun. 2008. Available from: $<$ https://www.sciencedirect. com/science/article/abs/pii/S0044848608000896>. Accessed: Mar. 29, 2016. doi: 10.1016/j.aquaculture.2008.02.019.

SCHVEITZER, R. et al. Use of artificial substrates in the culture of Litopenaeus vannamei (Biofloc System) at different stocking densities: Effects on microbial activity, water quality and production rates. Aquacultural Engineering, Florianópolis, v.54, p.93-103, May 2013. Available from: <https://www. sciencedirect.com/science/article/pii/S0144860912001100>. Accessed: Mar. 29, 2016. doi: 10.1016/j.aquaeng.2012.12.003.

SERRA, F.P. et al. Use of different carbon sources for the biofloc system adopted during the nursery and grow-out culture of Litopenaeus vannamei. Aquaculture International, Rio Grande, v.23, n.6, p.1325-1339, Dec. 2015. Available from: $<$ https://link. springer.com/article/10.1007/s10499-015-9887-6>. Accessed: May, 23, 2016. doi: 10.1007/s10499-015-9887-6.
STRICKLAND, J.D.H; PARSONS, T.R. A practical handbook of seawater analysis. Ottawa: Fisheries Research Board of Canada, 1972. 2ed.

UMESH, N.R. et al. Enhancing growth of common carp, rohu and Mozambique tilapia through plant substrate: the role of bacterial biofilm. Aquaculture International, Mangalore, v.7, n.4, p.251260, Jul. 1999. Available from: <https://link.springer.com/ article/10.1023/A:1009229113868\#citeas $>$. Accessed: Apr. 15, 2016. doi: 10.1023/A:1009229113868.

UNESCO (Org.). Chemical methods for use in marine environmental monitoring. Paris: Intergovernamental Oceanographic Commissiony, 1983. 12ed.

VAN WYK, P. \& SCARPA, J. Water Quality Requirements and Management. In: VAN WYK, P. et al. Farming marine shrimp in recirculating freshwater systems. Florida: Harbor Branch Oceanographic Institution, 1999. Cap.8, p.141-161.

YOKOKAWA, T.; NAGATA, T. Growth and grazing mortality rates of phylogenetic groups of bacterioplankton in coastal marine environments. Applied and Environmental Microbiology, Otsu, v.71, n.11, p.6799-6807, Nov. 2005. Available from: <https://www.ncbi.nlm.nih.gov/pmc/articles/ PMC1287730/>. Accessed: Apr. 06, 2016. doi: 10.1128/ AEM.71.11.6799-6807.2005.

WAGNER, M. etal. In situ analysis of nitrifying bacteria in sewage treatment plants. Water Science and Technology, Miinchen, v.34, n.1-2, p.237-244, 1996. Available from: <https://www. sciencedirect.com/science/article/pii/0273122396005148>. Accessed: Apr. 28, 2016. doi: 10.1016/0273-1223(96)00514-8. 